\title{
Recreational Water and Infection: A Review of Recent Findings
}

\author{
Lorna Fewtrell • David Kay
}

Published online: 22 January 2015

(C) The Author(s) 2015. This article is published with open access at Springerlink.com

\begin{abstract}
This paper reviews the latest evidence provided by epidemiological studies and quantitative microbial risk assessments (QMRAs) of infection risk from recreational water use. Studies for review were selected following a PubMed search for articles published between January 2010 and April 2014. Epidemiological studies show a generally elevated risk of gastrointestinal illness in bathers compared to non-bathers but often no clear association with water quality as measured by faecal indicator bacteria; this is especially true where study sites are impacted by non-point source pollution. Evidence from QMRAs support the lack of a consistent water quality association for non-point source-impacted beaches. It is suggested that source attribution, through quantified microbial source apportionment, linked with appropriate use of microbial source tracking methods should be employed as an integral part of future epidemiological surveys.
\end{abstract}

Keywords Epidemiology · Quantitative microbial risk assessment $\cdot$ Exposure $\cdot$ Gastrointestinal illness $\cdot$ Water quality $\cdot$ Point and non-point source pollution

\section{Introduction}

This paper reviews the recent literature related to recreational water use (in natural waters) and infection. It focuses on the

This article is part of the Topical Collection on Water and Health

\section{Fewtrell $(\bowtie) \cdot$ D. Kay}

Centre for Research into Environment and Health (CREH),

Department of Geography and Earth Sciences, Aberystwyth

University, Ceredigion SY23 3DB, UK

e-mail: 1jf@aber.ac.uk

D. Kay

e-mail: dvk@aber.ac.uk results of both epidemiological studies and quantitative microbial risk assessments (QMRAs), published between 2010 and mid-2014 (i.e., covering the period since the last World Health Organization (WHO) examination of this issue [1]), although some supporting and earlier papers are cited to provide additional context. Although the focus here is on infection (excluding exposure to cyanobacterial toxins), it is important to balance these findings against the health benefits and increased well-being that can result from interacting with natural surface waters [2] and recreational water in particular.

Recreational water users can be exposed to a range of disease-causing microorganisms, including those naturally present in water. Many of the infectious agents of concern in recreational water, however, are the result of faecal pollution (especially human). Sources of faecal pollution include sewage, surface runoff, domestic animals, and wildlife. Surveillance data from the United States of America (USA) showed that, during 2009 and 2010, there were 24 recreational water disease outbreaks associated with the use of natural waters, although 11 of these were attributed to cyanobacterial toxins. Microbial agents implicated included Campylobacter jejuni, E. coli O157:H7, Shigella sonnei, Cryptosporidium spp., Giardia intestinalis, norovirus, and avian schistosomes, with the largest outbreak due to norovirus [3]. Outbreak data have also shown that attack rates can be high, with two United Kingdom (UK) outbreaks $[4,5]$ relating to swimming events reporting attack rates between $31 \%$ (River Thames) and $85 \%$ (Strathclyde Loch).

Recreational water epidemiology goes back over 60 years with early studies being conducted in both the USA [6] and the UK [7]. Early studies observed exposure-response associations between enterococci and E. coli, commonly used bacterial indicators of faecal contamination in water, and gastroenteritis among bathers. As a result, enterococci, E. coli, and other indicators have been widely used to monitor the quality of recreational waters. Since that time, more sophisticated 
studies have been conducted, exploring different indicators of faecal pollution, different water users, and different environmental waters. Studies reported in the period 1990-2010 have been used to develop guidelines $[1,8]$ and standards $[9,10]$ designed to limit the health risk from recreational water exposures. The studies employed two broad protocols, a prospective beach survey in which the exposure status of the respondents was self-determined and a randomised controlled trial in which exposure status was randomised. Water quality in these studies was quantified for a range of indicators using both culture and molecular methods, with the quality to which bathers were exposed being assigned by either aggregate water quality measures (e.g., a daily average) or by a series of participant-specific levels. The United States Environmental Protection Agency (USEPA) criteria are largely based on a prospective survey design and include molecular methods for bacterial enumeration, while the WHO guidelines and European Union (EU) standards are based on a randomised control trial approach with culture methods to define microbial exposure.

\section{Epidemiology}

Papers published between 2010 and mid-2014, located through a PubMed keyword search, are summarised in Table 1 . A variety of keywords were used, including recreational water, marine water, freshwater, health, gastrointestinal, infection, and water quality. Epidemiological studies focusing on infection in recreational water users (excluding swimming pool users) were selected for review. Epidemiological studies have revealed a number of health impacts associated with recreational water use, including gastrointestinal illness, respiratory infections, eye infection, ear, nose, and throat complaints, and skin problems. However, gastrointestinal illness is the most commonly identified problem and also has formed the rationale for water quality criteria world-wide, so it is emphasised in Table 1.

The studies varied in how they defined bathers, with some gathering information on different degrees of exposure (splashed, body immersion, head immersion, swallowed water) and duration of recreational activity. The definition of gastrointestinal illness also varied between studies, with some being more rigorous than others. The non-exposed or control group was usually recruited at the same location, with the main exception being the study by Papastergiou [21] where non-bathers were recruited by telephone survey. Most recreators and non-recreators were self-selecting. The BEACHES study [15-17], however, randomised participants into bathing and non-bathing groups.

The ways in which water quality was assessed also varied between studies. A range of different possible indicators of faecal contamination were assessed (although all of the studies, except for Marion et al. 2010 [13], included enterococci measurements), using different methods of analysis (e.g., culture, plate counts and/or most probable number, and molecular) with different bather attribution techniques (e.g., personal sampling, daily averages, single daily sample).

While a statistically significant increase in gastrointestinal illness was not seen in all of the epidemiological studies, only Cordero et al. 2012 [19] reported a lower likelihood of gastrointestinal illness in bathers compared to non-bathers (AOR 0.88 ). Studies targeting beaches polluted by point sources of faecal pollution (e.g., Wade et al. 2010 [23]) generally reported results supporting earlier work (i.e., a relationship between gastrointestinal illness and microbial indicator concentration).

The importance of being aware and accounting for local conditions is illustrated by two studies $[18 \bullet, 25]$ where the risk of swimming-related gastrointestinal illness was elevated when stream [18 ${ }^{\bullet}$ and submarine groundwater discharge [25] was high. In both cases there was a relationship between water quality and gastrointestinal illness only when the pollution sources were discharging to the recreational water.

\section{Non-point Source Pollution}

Until relatively recently, epidemiological studies have tended to focus on bathing locations with known point sources of human faecal pollution and it is these studies that established relationships between faecal indicator bacteria and the risk of gastrointestinal illness [26, 27].

Non-point sources can include storm water runoff, septic tank drainage, sand re-suspension, animal faecal inputs, and human bather shedding and, thus, may or may not contain human faecal inputs.

Of the ten studies summarised in Table 1, five focus on non-point source-impacted locations [13-17, 18•, 20, 21]. The only study to address freshwater non-point sources [13] identified a relationship between gastrointestinal illness and E. coli for concentrations above $11 \mathrm{cfu} / 100 \mathrm{ml}$. In the marine studies, generally, where there was a significant difference in gastrointestinal illness between bathers and non-bathers [14, $18 \cdot, 21]$, no relationships were seen between the risk of illness and water quality parameters (this was also true of an earlier study [28]). The one exception is the study by [18•], where there was a suggestion of a relationship between enterococci (measured by culture or molecular methods) and the risk of diarrhoea but only on 'berm-open' days, when polluted stream water was discharged to the marine bathing area.

\section{Bathers as a Source of Non-point Pollution}

It has been suggested that bathers may act as a source of pollution in their own right, either by shedding microorganisms from their bodies or by stirring up polluted sand and sediment. 


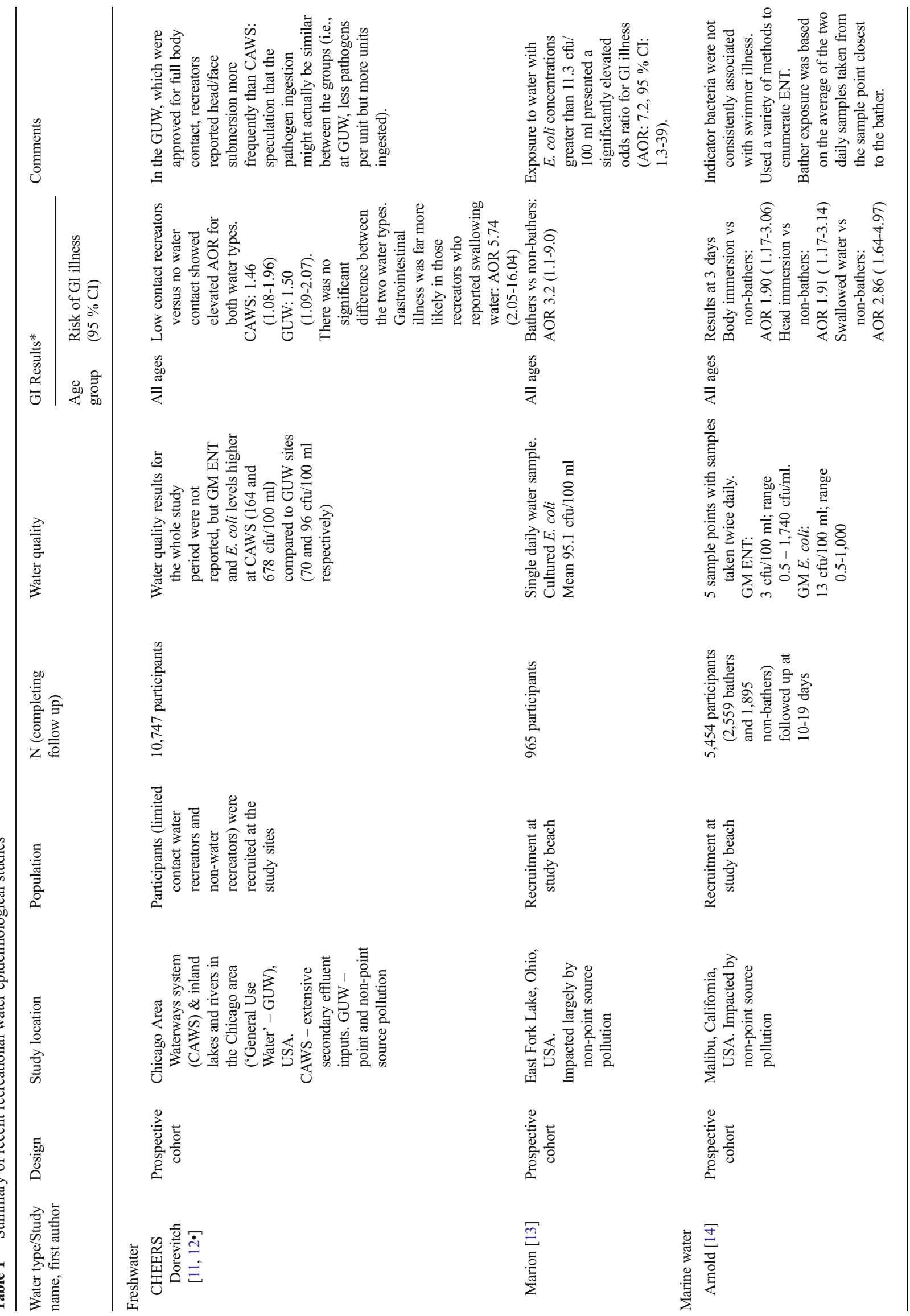




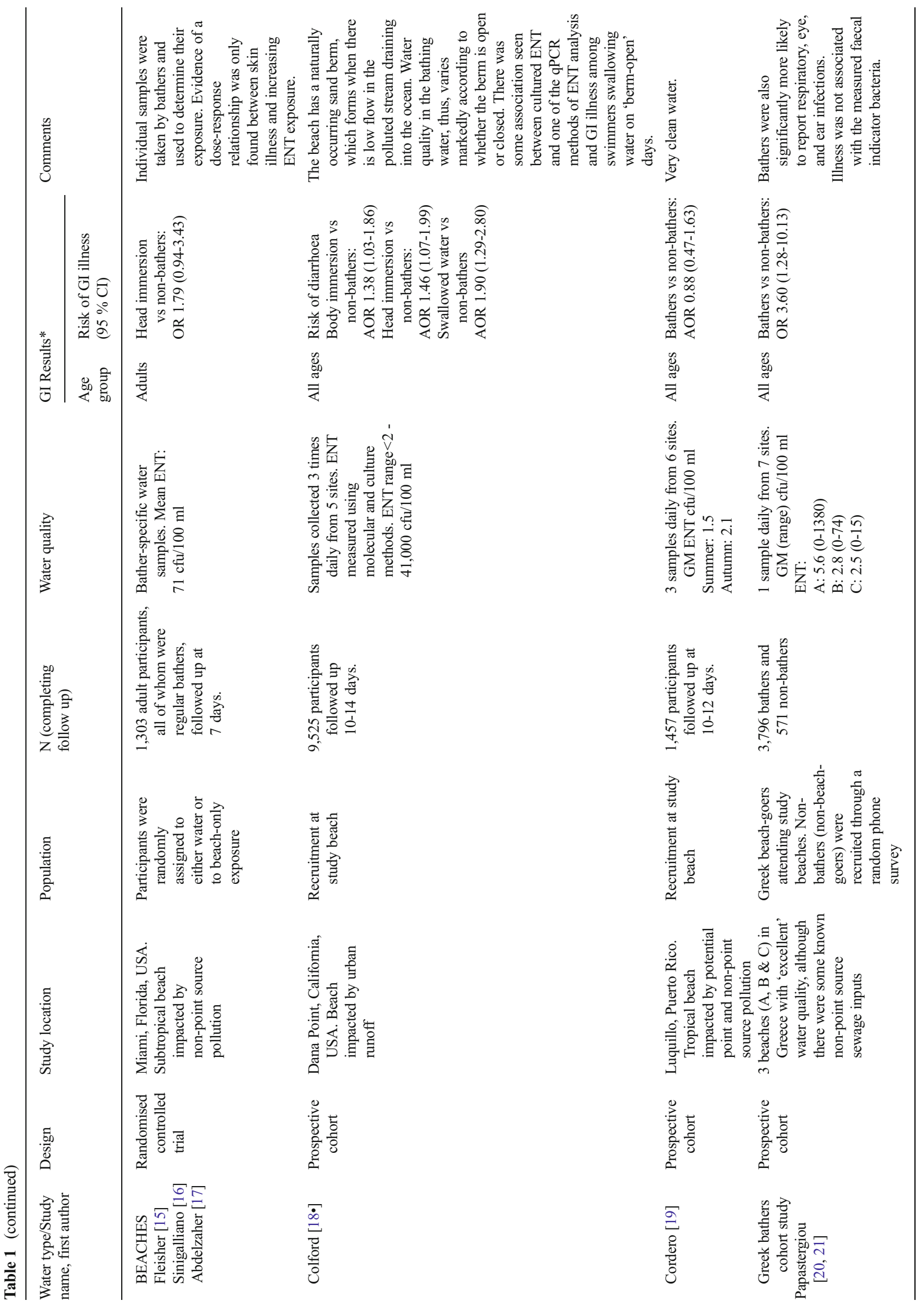




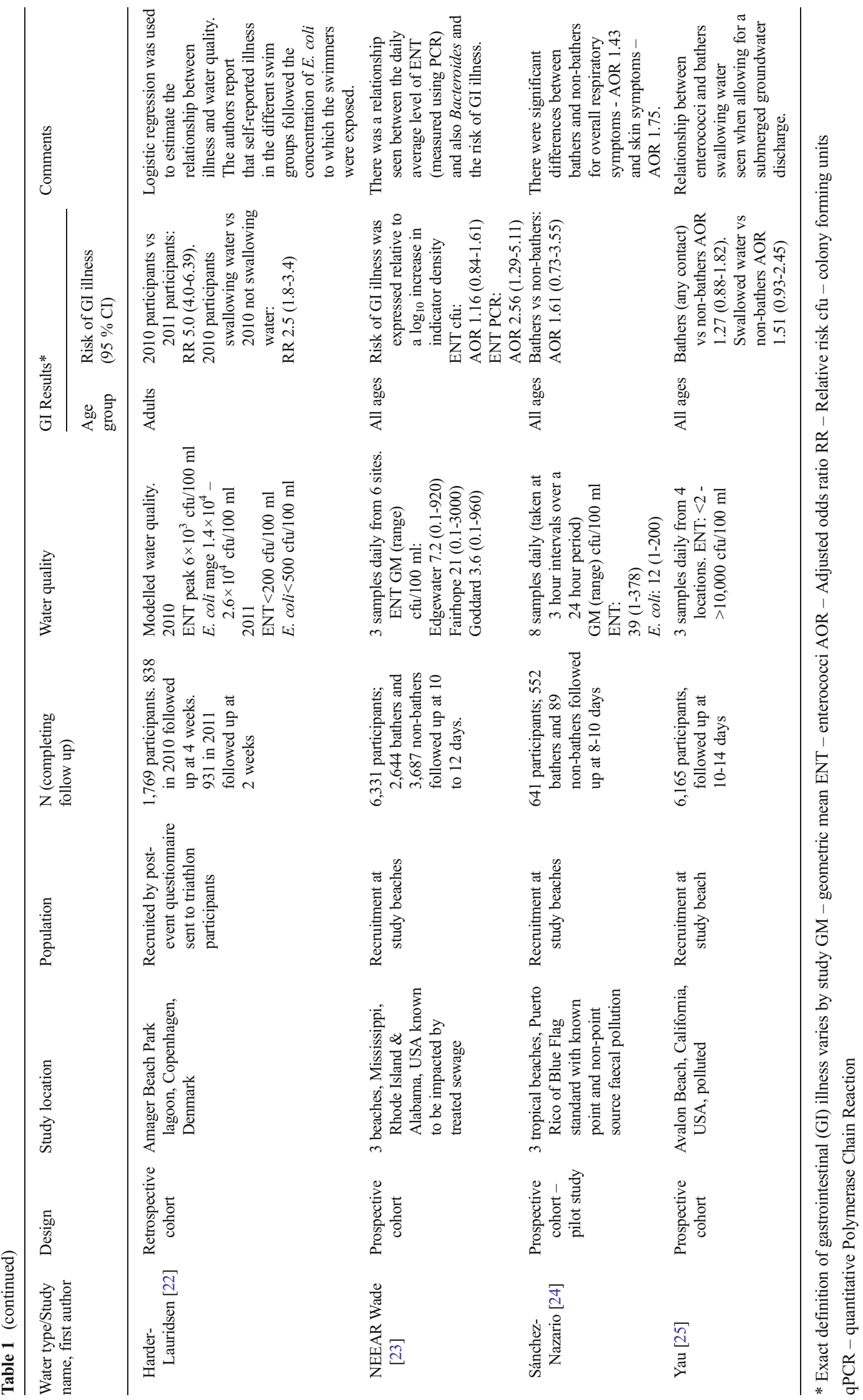


Papastergiou $[20,21]$ did not find a relationship between gastrointestinal illness and indicator bacteria (Table 1) at three beaches with 'excellent' water, but they did find an association between bather density and both gastrointestinal [OR 2.13, $95 \%$ confidence interval (CI) 1.95-3.79] and respiratory illness (OR 2.99, $95 \%$ CI 1.64-5.46). Beach A (with a median bather density of 1.41 bathers $/ 100 \mathrm{~m}^{3}$ ) was used as the baseline and compared to illnesses reported by bathers at beaches B \& C (median densities of 2.91 and 21.65 bathers $/ 100 \mathrm{~m}^{3}$, respectively). It was presumed that the increased illness was caused by bather to bather transmission via the water (gastrointestinal illness) and air (respiratory pathogens).

Graczyk [29] found a significant relationship between bather numbers at a marine beach in the USA and turbidity. The detection of three selected pathogens was significantly correlated with both enterococci levels and bather density. It was thought that the bathers were causing re-suspension of bottom sediments, which resulted in the elevated levels of enterococci and pathogens seen when bather numbers were high.

\section{Sand}

Sand has been suggested as a possible sink for faecal pollution and, in a recent review [30], it was noted that faecal indicator bacteria were usually found in significantly higher concentrations in sand than in water samples. Sand could, therefore, present an infection risk in its own right [31] as well as potentially negatively impacting water quality. One study in Puerto Rico (Sánchez-Nazario et al. 2014 [24]) took sand samples and reported geometric mean enterococci levels of $97 \mathrm{cfu} /$ $100 \mathrm{~g}$ and $39 \mathrm{cfu} / 100 \mathrm{ml}$ in sand and water, respectively. The 'BEACHES' study in Florida also collected and analysed sand samples prior to the epidemiological study, with enterococci levels of $4-1,088 \mathrm{cfu} / \mathrm{g}$ reported, along with the isolation of Cryptosporidium spp. [32]. As part of The National Epidemiological and Environmental Assessment of Recreational Water Study (NEEAR study), wet sand samples were taken from two of the beaches (Fairhope and Goddard) and participants were asked about sand contact and water-related activities [33•]. Digging in the sand was strongly associated with swimming $(81 \%$ of swimmers reported digging in the sand compared to $19 \%$ of the non-bathers). However, after adjusting for swimming, sand enterococci concentration determined by culture methods was positively associated with both sand digging and gastrointestinal illness (AOR 1.7; $95 \%$ CI 1.1-2.7).

\section{Animal Inputs}

Where there are non-point source inputs, it is difficult to establish whether pollution is due to animal or human sources and it is known that animal inputs can contribute substantially to faecal indicator loads. Converse [34], for example, found that gull removal (using dog harassment techniques) led to notable improvements in beach water quality, with a $50 \%$ reduction in gull numbers associated with a $38 \%$ decrease in enterococci concentration. Wang [35], on the other hand, examined a non-point source-impacted beach in Miami-Dade County, USA and estimated the contributions to enterococci load made as a result of bird and dog visitations (the only beach in the county allowing dogs). In this case, gulls were found to contribute relatively little to the load (with estimates varying between $10^{3}-10^{5} \mathrm{cfu} /$ day), while dogs were responsible for a much greater estimated load $\left(10^{9}-10^{10} \mathrm{cfu} / \mathrm{day}\right)$. Dufour [36] reviewed a number of epidemiological studies, all conducted before 2010, and found that there was no evidence for associations between swimming-associated gastrointestinal illness and exposure to natural recreational water polluted with faeces from non-human sources.

\section{Use of Molecular Methods for Indicator Enumeration}

Culture techniques for the enumeration of indicator bacteria tend to take a long time to produce results, with an incubation period of at least 24 hours, and so a number of more rapid techniques are being investigated in the hope that data can be produced more quickly in order to improve management decisions. It is, thus, becoming fairly common for molecular (especially quantitative polymerase chain reaction - qPCR) as well as traditional culture methods to be used for indicator analyses in epidemiological studies [14-17, 18•, 19, 23, 28]. Studies typically report quite different results depending on the method of analysis [37] and, where results are given for enterococci for both culture and PCR methods, greater concentrations are reported with PCR.

Some epidemiological studies, principally at point sourcepolluted locations, have reported an association between enterococci measured using PCR and gastrointestinal illness $[18 \cdot, 23,38,39]$. The clearest relationships are those reported by Wade $[23,38,39]$ who considered a number of beaches impacted by human sewage. At four freshwater beaches [38, 39 ], an association was found between the daily average $\log _{10}$ qPCR cell equivalents for enterococci and gastrointestinal illness in water users (AOR 1.26; $95 \%$ CI 1.06-1.51), with a stronger association seen for children aged ten and younger (AOR 1.69; $95 \%$ CI 1.24-2.30). In the study of three marine beaches [23] (Table 1), a $\log _{10}$ increase in daily average enterococci measured by PCR was found to result in an increased AOR of 2.56 (95\% CI 1.29-5.11). Enterococci measured by culture were also positively associated with gastrointestinal illness, but the association was not statistically significant. Unlike the freshwater sites, children at the marine beaches did not show increased susceptibility to illness with exposure to enterococci. The water quality and gastrointestinal illness association seemed to strengthen when swallowing water (AOR 8.9; $95 \%$ CI 2.2-37) or spending over 90 minutes in the water (AOR 6.4; $95 \%$ CI 1.2-33). 


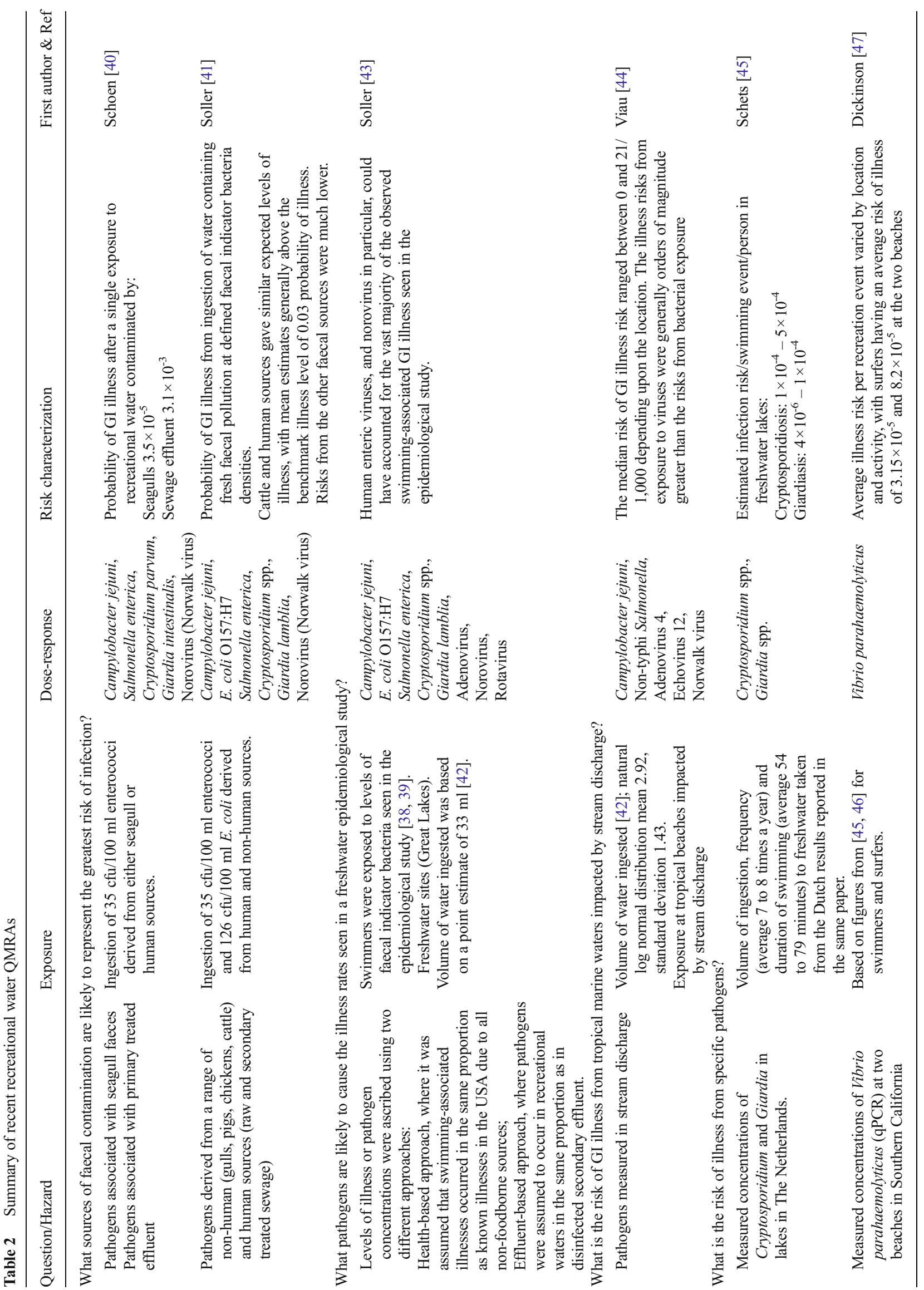


Quantitative Microbial Risk Assessment (QMRA)

This is a fairly new tool for those interested in the likely health impacts related to recreational water use and it allows for exploration of different scenarios; it can be used to augment and complement recreational water epidemiological studies.

Table 2 summarises recent recreational water QMRAs by the four QMRA steps, as follows: hazard identification, exposure assessment, dose-response assessment, and risk characterization. Studies were identified through a PubMed search using keywords similar to those for the epidemiology search (with the addition of microbial, exposure, and risk assessment) and selected to illustrate a number of relevant questions. As can be seen, recent examples employ a range of different approaches and explore a variety of areas, including those that would be difficult to subject to an epidemiological study. They do, however, require a number of assumptions and they are limited by the pathogens for which dose-response relationships are available.

The QMRA studies support the findings from the epidemiology in relation to the different results seen between point source-polluted and non-point source-polluted recreational water, as they show that risk depends on the source of faecal pollution and that, as viruses seem to be the pathogens of concern, human sewage inputs carry the greatest risk of infection. In addition, infection risks seem to be greater after rainfall.

\section{Conclusions}

Epidemiological papers published after 2009, using both prospective beach survey and randomised control trial protocols, suggest an elevated health risk due to bathing water exposure. However, for the most part, they generally failed to quantify a distinct and credible linear relationship of the type used by regulators in the design of existing standards (an exception being the study by Wade [23] and gastrointestinal illness and enterococci measured by PCR). It would be too simplistic to attribute this failure to misclassification bias caused by the use of aggregate measures of exposure. It could be that the considerable expenditures devoted to collection and treatment of human sewage in the past 50 years in all developed nations has resulted in reductions of the principal faecal loading from the human population, which drives the pathogenic virus flux implicated in many outbreaks, symptom elevations reported world-wide, and as suggested by QMRAs. It should be noted, however, there is still a consistent elevation in illness among the bather cohort in most studies which could relate to residual microbial loadings from intermittent discharges from a sewerage system after rainfall events, polluted urban flows with impaired water quality due to improper cross-connections to the sewerage system, poorly treated sewage caused by plant overloading after population growth or sewerage extension, 
and, finally, human pathogens derived from livestock farming areas, generally comprising protozoan or bacterial pathogens.

Source attribution, through quantified microbial source apportionment, linked with appropriate use of microbial source tracking methods should, therefore, be employed as an integral part of future epidemiological surveys. In addition, protocols defining exposure (i.e., aggregate measures vs spot determinations) should be integrated with the design of bathing water compliance requirements. Here, many authorities are effectively moving towards aggregate measures such as percentile or geometric mean values and away from allowed thresholds. It would be wise for the research and regulatory communities to examine the impact of natural variability in environmental faecal indicator concentrations on the precision and, hence, credibility of either approach as a predictor of health risk, whether culture or molecular methods of enumeration are deployed. Finally, on the choice between culture and molecular methods, there is a clear need for re-examination of the precision and reproducibility of both approaches and their differential attenuation through common sewage treatment and disinfection systems. This is required to allow the regulatory community to make objective choices between available systems.

Acknowledgments This paper, by the $\mathrm{C} 2 \mathrm{C}$ (Cloud to Coast) team, was jointly funded by the Natural Environment Research Council (NERC), Medical Research Council (MRC), Department for Environment, Food \& Rural Affairs (Defra) and Economic \& Social Research Council (ESRC), as part of the Living With Environmental Change (LWEC) (Environmental Exposure \& Health Initiative (EEHI)) programme. Grant reference GR $\mathrm{NE} / \mathrm{I} 008306 / 1$

\section{Compliance with Ethics Guidelines}

Conflict of Interest Lorna Fewtrell and David Kay declare that they have no conflict of interest.

Human and Animal Rights and Informed Consent This article does not contain any studies with human or animal subjects performed by any of the authors.

Open Access This article is distributed under the terms of the Creative Commons Attribution License which permits any use, distribution, and reproduction in any medium, provided the original author(s) and the source are credited.

\section{References}

Papers of particular interest, published recently, have been highlighted as:

- Of importance

1. WHO. Addendum to the WHO Guidelines for safe recreational water environments, volume 1 , coastal and fresh waters. List of agreed updates. Geneva: World Health Organization; 2009.
2. Völker S, Kistemann T. The impact of blue space on human health and well-being - salutogenetic health effects of inland surface waters: a review. Int J Hyg Environ Health. 2011;214:449-60.

3. Hlavsa MC, Roberts VA, Kahler AM, et al. Recreational waterassociated disease outbreaks - United States, 2009-2010. Morb Mortal Wkly Rep. 2014;63:6-10.

4. PHE. Epidemiological investigation of an outbreak of gastrointestinal illness following a mass participation swim in the River Thames London October 2012. Public Health England 2013.

5. Logan J. The Strathclyde Loch norovirus outbreak. NHS Lanarkshire Public Health 2012/2013. The annual report of the Director of Public Health, 2013.

6. Stevenson AH. Studies of bathing water and health. Am J Public Health. 1953;43:529-38.

7. PHLS. Sewage contamination of coastal bathing waters in England and Wales - a bacteriological and epidemiological study. J Hyg. 1959;57:435-72.

8. WHO. Guidelines for safe recreational-water environments, volume 1, coastal and fresh-waters. Geneva: World Health Organization; 2003.

9. USEPA. Recreational water quality criteria. Office of Water 820-F12-058; 2012.

10. EU. Directive 2006/7/EC of the European Parliament and of the Council of 15 February 2006 concerning the management of bathing water quality and repealing Directive 76/160/EEC. Official Journal of the European Union; 2013: L64/37.

11. Dorevitch S, Dworkin MS, DeFlorio SA, et al. Enteric pathogens in stool samples of Chicago-area water recreators with new-onset gastrointestinal symptoms. Water Res. 2012;46:4961-72.

12. Dorevitch S, Pratap P, Wroblewski M, et al. Health risks of limitedcontact water recreation. Environ Health Perspect. 2012;120:192-7. This demonstrates that even low-contact activities may carry an elevated risk of gastrointestinal illness compared to no water contact, although the risk is still driven by water ingestion.

13. Marion JW, Lee J, Lemeshow S, et al. Association of gastrointestinal illness and recreational water exposure at an inland U.S. beach. Water Res. 2010;44:4796-804.

14. Arnold BF, Schiff KC, Griffith JF, et al. Swimmer illness associated with marine water exposure and water quality indicators: Impact of widely used assumptions. Epidemiology. 2013;24:845-53.

15. Fleisher JM, Fleming LE, Solo-Gabriele HM, et al. The BEACHES study: health effects and exposures from non-point source microbial contaminants in subtropical recreational marine waters. Int $\mathrm{J}$ Epidemiol. 2010;39:1291-8.

16. Sinigalliano CD, Fleisher JM, Gidley ML, et al. Traditional and molecular analyses for fecal indicator bacteria in non-point source subtropical recreational marine waters. Water Res. 2010;44:376372.

17. Abdelzaher AM, Wight ME, Ortega C, et al. Daily measures of microbes and human health at a non-point source marine beach. $\mathrm{J}$ Water Health. 2011;9:443-57.

18. Colford Jr JM, Schiff KC, Griffith JF, et al. Using rapid indicators for Enterococcus to assess the risk of illness after exposure to urban runoff contaminated marine water. Water Res. 2012;46:2176-86. This study demonstrates the importance of understanding local conditions and how variations may impact on bather risk.

19. Cordero L, Norat J, Mattei H, et al. Seasonal variations in the risk of gastrointestinal illness on a tropical recreational beach. J Water Health. 2012;10:579-93.

20. Papastergiou P, Mouchtouri VA, Rachiotis G, et al. Bather density as a predominant factor for health effects related to recreational bathing: Results from the Greek bathers cohort study. Mar Pollut Bull. 2011;62:590-5.

21. Papastergiou P, Mouchtouri V, Pinaka O, et al. Elevated bathingassociated disease risks despite certified water quality: a cohort study. Int J Environ Res Public Health. 2012;9:1548-65. 
22. Harder-Lauridsen NM, Kuhn KG, Erichsen AC, et al. Gastrointestinal illness among triathletes swimming in nonpolluted versus polluted seawater affected by heavy rainfall, Denmark, 2010-2011. PLoS One. 2013;8:e78371. doi:10.1371/ journal.pone.0078371.

23. Wade TJ, Sams E, Brenner KP, et al. Rapidly measured indicators of recreational water quality and swimming-associated illness at marine beaches: a prospective cohort study. Environ Health. 2010;9: 66.

24. Sánchez-Nazario EE, Santiago-Rodriguez TM, Toranzos GA. Prospective epidemiological pilot study on the morbidity of bathers exposed to tropical recreational waters and sand. J Water Health. 2014;12:220-9.

25. Yau VM, Schiff KC, Arnold BF, et al. Effect of submarine groundwater discharge on bacterial indicators and swimmer health at Avalon Beach, CA, USA. Water Res. 2014;59:23-36.

26. Prüss A. Review of epidemiological studies on health effects from exposure to recreational water. Int J Epidemiol. 1998;27:1-9.

27. Wade TJ, Pai N, Eisenberg JN, et al. Do US environmental protection agency water quality guidelines for recreational waters prevent gastrointestinal illness? Environ Health Perspect. 2003;111:1102-9.

28. Colford JM, Wade TJ, Schiff KC, et al. Water quality indicators and the risk of illness at beaches with nonpoint sources of fecal contamination. Epidemiology. 2007;18:27-35.

29. Graczyk T, Sunderland D, Awantang GN, et al. Relationships among bather density, levels of human waterborne pathogens, and fecal coliform counts in marine recreational beach water. Parasitol Res. 2010;106:1103-8.

30. Halliday E, Gast RJ. Bacteria in beach sands: an emerging challenge in protecting coastal water quality and bather health. Environ Sci Technol. 2011;45:370-9.

31. Yamahara KM, Sassoubre LM, Goodwin KD, et al. Occurrence and persistence of bacterial pathogens and indicator organisms in beach sand along the California coast. Appl Environ Microbiol. 2012;78: 1733-45.

32. Abdelzaher AM, Wright ME, Ortega C, et al. Presence of pathogens and indicator microbes at a non-point source subtropical recreational marine beach. Appl Environ Microbiol. 2010;76:724-32.

33. Heaney CD, Sams E, Dufour AP, et al. Fecal indicators in sand, sand contact, and risk of enteric illness among beachgoers. Epidemiology. 2012;23:95-106. A study specifically considering the possibility of sand as an additional/alternative route of gastrointestinal illness transmission.

34. Converse RR, Kinzelman JL, Sams EA, et al. Dramatic improvements in beach water quality following gull removal. Environ Sci Technol. 2012;46:10206-13.

35. Wang JD, Solo-Gabriele HM, Abdelzaher AM, et al. Estimation of enterococci input from bathers and animals on a recreational beach using camera images. Mar Pollut Bull. 2010;60:1270-8.
36. Dufour A, Wade TJ, Kay D. Epidemiological studies on swimmer health effects associated with potential exposure to zoonotic pathogens in bathing beach water - a review. In: Dufour A, Bartram J, Bos R, Gannon V, editors. Animal Waste, Water quality and Human Health. London: IWA publishing; 2012. p. 415-28.

37. Shibata T, Solo-Gabriele HM, Sinigalliano CD, et al. Evaluation of conventional and alternative monitoring methods for a recreational marine beach with nonpoint source of fecal contamination. Environ Sci Technol. 2010;44:8175-81.

38. Wade TJ, Calderon RL, Sams E, et al. Rapidly measured indicators of recreational water quality are predictive of swimming-associated gastrointestinal illness. Environ Health Perspect. 2006;114:24-8.

39. Wade TJ, Calderon RL, Brenner KP, et al. High sensitivity of children to swimming-associated gastrointestinal illness: results using a rapid assay of recreational water quality. Epidemiology. 2008;19: 375-83.

40. Schoen ME. Ashbolt NJ (2010) Assessing pathogen risk to swimmers at non-sewage impacted recreational beaches. Environ Sci Technol. 2010;44:2286-91.

41. Soller JA, Schoen ME, Bartrand T, et al. Estimated human health risks from exposure to recreational waters impacted by human and non-human sources of faecal contamination. Water Res. 2010;44: 4674-91.

42. Dufour AP, Evans O, Behymer T, et al. Water ingestion during swimming activities in a pool: a pilot study. J Water Health. 2006;4:425-30.

43. Soller JA, Bartrand T, Ashbolt NJ, et al. Estimating the primary etiologic agents in recreational freshwaters impacted by human sources of faecal contamination. Water Res. 2010;44:4736-47.

44. Viau EJ, Lee D, Boehm AB. Swimmer risk of gastrointestinal illness from exposure to tropical coastal waters impacted by terrestrial dry-weather runoff. Environ Sci Technol. 2011;45:7158-65.

45. Schets FM, Schijven JF, de Roda Husman AM. Exposure assessment for swimmers in bathing waters and swimming pools. Water Res. 2011;45:2392-400.

46. Stone D, Harding A, Hope B, et al. Exposure assessment and risk of gastrointestinal illness among surfers. J Toxicol Environ Health A. 2008;71:1603-15.

47. Dickinson G. Lim K-y, Jiang SC. Quantitative microbial risk assessment of pathogenic vibrios in marine recreational waters of Southern California. Appl Environ Microbiol. 2013;79:294-302.

48. Tseng LY, Jiang SC. Comparison of recreational health risks associated with surfing and swimming in dry weather and post-storm conditions at Southern California beaches using quantitative microbial risk assessment (QMRA). Mar Pollut Bull. 2012;64:912-8.

49. McBride GB, Stott R, Miller W, et al. Discharge-based QMRA for estimation of public health risks from exposure to stormwater-borne pathogens in recreational waters in the United States. Water Res. 2013;47:5282-97. 